It cannot, I think, be too clearly impressed on the student that, when any quantity is expressed by a number, that number is the ratio of the quantity to some standard of the same kind.

To take the preceding example, $f$ is the number of feet in the height $h$.

$$
\begin{aligned}
& \text { i.e. } h=f \text { feet, } \\
& \therefore f=\frac{h}{\mathrm{I} \text { foot }}=\text { the ratio of } h \text { to } \mathrm{I} \text { foot. } \\
& \text { Similarly } m=\frac{d}{\text { I mile }}=\text { the ratio of } t \text { to I mile. }
\end{aligned}
$$

So that the full expression for the relation $f=\frac{2}{3} m 2^{2}$ is :-

$$
\frac{\text { height }}{\mathrm{I} \text { foot }}=\frac{2}{3} \text { of }\left[\frac{\text { distance }}{\mathrm{I} \text { mile }}\right]^{2} \text {. }
$$

My position, therefore, as regards numerical equations, is this: That the numbers which appear are only short methods of stating pure ratios, and that such short methods are eminently useful in clealing with practical problems, but do not help a student to grasp the fundamental principles of a subject.

There is another simple way in which numerical equations can be deduced from the fundamental ones; viz. by so choosing the standards of measurement that every term may be expressed in terms of the same standard, which may then be omitted, leaving only a relation among the numerical coefficients of that standard.

To enable this to be done, all the stanclards of subsidiary quantities are so chosen that, when expressed in terms of certain primary standards, their coefficients shall be unity. When this is sy:tematically done, all the standards are usually called units, apparently because if you arbitrarily put unity for each primary standard, the subsidiary ones will become equal to unity also.

For example, if a foot and a second are chosen units of length and time, a foot per second is the unit of velocity. For, the full expression for a foot per second is $\begin{aligned} & \mathrm{I} \text { foot } \\ & \mathrm{I} \mathrm{sec.} \text {; and if you put I foot }\end{aligned}$ $=\mathrm{I}$, and I sec. $=\mathrm{I}$, the fraction $\frac{\mathrm{I} \text { foot }}{\mathrm{I} \text { sec. }}$ becomes equal to $\mathrm{I}$

This plan certainly enables the working numerical equations to be very easily deduced from the fundamental ones, with which indeed thi:y thus become identical in form, but there is great danger lest this fact should make us lose sight of the important fact that they are only special deductions from the higher kind of equation-from the true funclamental equations which exist among the quantities themselves.

\section{DISCOVERY OF ELEPHAS PRIMIGENIUS ASSOCIATED WITH FLINT IMPLEMENTS AT SOUTHALL.}

A PAPER with the above title was lately read by Mr. J. Allen Brown before the Geologists' Association. It is of more than ordinary interest to geologists since an attempt has lately been made to show that the mammoth became suddenly extinct by the action of a vast flood seemingly universal in its operation, due to some convulsion or cataclysm, which also changed the climate of Northern Europe.

During last year some important drainage works were carried out at Southall, and sections were exposed in the IVindmill Lane, a road running from Greenford, through IIanwell, across the Great Western Railway to Woodlake, skirting Osterley Park, as well as in Norwood Lane, leading from Windmill Lane, south-westward.

The remains of the mammoth were discovered in Norwood Lane at the 88. foot contour, about 550 yards from its junction with the Windmill Lane. They were embedded in sandy loam, underlying evenly stratified sandy gravel, with a thin deposit of brick earth, about $\mathrm{I}$ foot in thickness, surmounting the gravel--in all, about 13 feet above the fossils. The tusks were found curving across the shere or excavation, attached to the skull, parts of which, with the leg-bones, teeth, \&c., were exhumed, other hones being seen embedded in one side of the cutting. Probably the entire skeleton might have been removed if the excavation could have been extended, and if there had been appliances at hand for removing the fossils, which were in a soft pulpy condition.

The author obtained some of the bones in a fragmentary state, including parts of the fore-limbs and jaw, with portions of the tusks as well as two of the three teeth found, which were much better preserved. The remains were quite unrolled, and the joints and articulations of the leg-bones and the teeth were unabraded. There can hardly be a doubt, from the report of the workmen, that the bones of the fore-part of the elel hant, if not of the entire slieleton, were in juxtaposition.

Several implements were found in Norwood Lane, in close proximity to the remains, and a "ell-formed spear-head, nearly 5 inches in length, of exactly the same shape as the spear-heads of obsidian until recently in use among the natives of the Admiralty Islands, and other savages, was discovered in actual contact with the bones; smaller spear-head flakes, less symmetrically worked, were also found at this spot. They are formed for easy insertion into the shafts by thinning out the butt ends, similar to these found abundantly by the author at the workshop floor, Acton, and descrited hy him in his recently published work, "Palzeolithic Man in North-West Middlesex." Among the implements found at this spot are an unusually fine specimen of the St. Acheul or pointed type, 8 inches long, of rich ochreous colour and unabraded, and a well formed lustrous thick oval implement pointed at one extremity, rounded at the other, about 5 inches in length, also unrolled.

From the adjacent excavations in the Windmill Road several good specimens of Palæolithic work were also obtained, including two dagger implements, with heavy unworked butts, and incurved sides converging to a long point; these were evidently intended to be used in the hand without hafting. Also an in-trument characteristic of the older river drift, convex on one side, and slightly concave on the other near the point, and partly worked at the but. With these were two rude choppers or axes, two points of implements with old surfaces of fracture, a shaft-smoother or spcke-shave, and several fiakes.

It is remarkable that most of the principal types of flint implements which characterize the olclest river-drift deposits are represented in this collection from the vicinity of the remains of the elephant.

Mr. J. Allen Brown accounts for the deposit of fossils and associated human relics at this locality by the fact that the underlying Eocene bed rises to within 2 or 3 feet of the surface a few yards west of the spot where the bones and implements were found, while towards the Uxbridge Road and upper part of the Windmill Lane the drift. deposits thicken, until at no great distance they have a thickness of 14 to 17 feet. Thus the river drift rapidly thins out, and the upward slope of the London Clay reaches nearly to the surface at about the go-foot contour. As the level at which the fossils were found ( 13 feet from the surface) would represent the extent of the erosion and in-filling of the valley which had taken place, it is probable that the higher ground formed by the up-slope of the Loncion Clay then formed the banks of the ancient river; or if another thick bed of clrift should be found still further west in a depression of the Tertiary bed such as often occurs, the intervering higher ground would form an island in the stream. In either case a habitable land surface would be formed $\mathrm{w}$ ith shallow tranquil water near the banks, not impinged upon by the current, which afterwards set in the direction of this spot as shown by the coarser slatified gravel above the loamy bed and remains.

The author is thus led to the conclusion either that the carcass of the elephant drifted into the shallow tranquil water near the bank, or else, as seems more probable from the presence of to many weapons near the spot, including the spear-head found with the remains, that the animal was pursued into the shallow water by the Palæolithic hunters and there became bogged. Whatever hypothesis may be accepted, there is no evidence of any greater flood or inundation than would often occur, under the severe climatal conditions which prevailed during the long period that intervened between the formation of the higher brenches of river clrift and that of the mid terrace, only 25 to 30 feet above the present river, in which the remains of the mammoth and the extinct Quaternary Mammalia are more frequently met with under sinilar conditions. Nor does there appear to be any more reason for ascribing the extinction of the great Quaternary Pachylerms to a sudden caiastrrphe or cataclysm than there is for the extinction of some other Pleistocene animals, such as the great Irish ell, which lived on into, or nearly into, historic times. The difficulty involved in this hypothesis is still further increased by the fact that other animals, such as the reindeer and others of northern habit, as well as southern forms like the hippopotamus, were not 
utterly destroyed with their contemporaries by the same cause, but merely migrated to regions more suited to them, as the climate and other conditions of this country changed.

Exhibits. - Bones, teeth, and part of the tusks of mammoth, and associated flint implements from Southall. A flint implement from the lacustrine (?) bed at the Mount, Ealing (I90 to 200 O.D.) (See the author's paper, Proceedings Geologists' As-ociation, vol. $x$. No. 4). A flint apparently worked by man from the Weybourn Crag, beneath the "Forest bed" near Cromer. A Palæolithic scraper found on the beach near Cromer, \&c.

\section{THE POISONOUS SNAKES OF THE BOMBAY PRESIDENCY.}

$A T$ a recent meeting of the Bombay Natural History Society, a paper was read by the Honorary Secretary. Mr. H. M. Phipson, on the "Poisonous Snakes of the Hombay Presidency." $\mathrm{He}$ produced for inspection specimens of the following poisonous snakes, all of them having been killed in the Presidency of Bombay.

Colubrine.--(1) Ophiophagus clats; (2) Naga tripudians, (3) Bungarus arcuatus; (4) Callophis trimaculatus; (5) Callophis nigre:cens.

Viperine. - (6) Daboic elegans; (7) Echis carinata; (8) Trimeresurus anamallenis; (9) Hypnale nepa.

With regard to the first species, the Ophiophagus elaps, it is perhaps the largest poisonous snake in the world, sometimes measuring over 15 feet. It is also called the "king cobra" or "hamadryad," and is not very common, though widely diffused, being found in the Andamans, the Philippines, Borneo, Java, and Sumatra. On account of expanding a "hood," it is frequently misiaken for the cobra, but the head-shields of the hamadryad differ very much from those of the cobra. The second species, Naga tripudians, or cobra, is found all over India, and up to the height of 8000 feet in the Himalayas. There are many varieties, differing in colour and marking, to which the natives give different names, thinking them distinct species; but in such matters the native knowledge is not very extensive. Thus they believe that all the hooded cobras are females, and that the males are harmless. What they call the male is in reality only the common Indian rat snake (Ptyas mucosus). They also state that the rat snake is proof against the poison of the cobra. But this is not the case. Last year the young ones hatched in the Society's rooms attacked a small Malay python put into their cage, when they were only a few days old, and bit at it viciously, and the python died in a few hours after its removal to another cage. Once a year, during the rainy season, the cobra lays from twelve to twenty eggs. In one specimen shown by Mr. Phipson, the young one is seen just as it is emerging from the egg. The tooth with which it cuts its way out is shed as soon as it has served its purpose. IVhen born, the young cobras measured about $7 \frac{1}{1}$ inches long, and were very fat ; but at the end of a few months they were about 9 inches in length, but had lost all their plumpness. It is very remarkable that the original nutriment got out of the egg should be able to sustain them so long. Un account of its timidity and the great ease with which it can be tamed, it is the only snake with which the snakecharmers will have anything to do. By attracting its attention with one hand, it may be easily seized round the body with the other ; and so long as the hand or any other object is kept moving before its eyes, it will never turn to bite the hand that holds it. This is the simple fact the knowledge of which the charmers turn to such advantage in their well-known performances. The snake is taken from its basket, and a slight stroke across the back brings it at once into a defensive attitude. The constant motion of the musical instrument before the snake keeps it watchful and erect, and not the music produced. As a matter of fact, snakes have no external ears, and it is extremely doubtful whether the cobra hears the music at all. The charmers say that the adder of the East, the Daboia, has no ear for music, because they cannot operate on it as they do on the cobra. It is rather interesting to note that this has been the belief since David's time at least- "like the deaf adder that stoppeth her ear; which will not hearken to the voice of charmers." (3) The krait (Bungarus arcuatus) is an exceedingly poisonous snake, and is quite common in nearly every part of India. One specimen taken in the Bombay Presiclency contained a "brown tree snake" (Dipsas gokool) and in another specimen was found a Ptyas mucosus, thus showing that this species eats snakes. The common Lycodsn aulicus, one of the non-poisonous snakes, is very much like the krait, but they can be distinguished by the presence in the krait of large hexagonal scales down the centre of the back. (4) The Callophis trimaculatus has no popular name. It is undoubtedly poisonous, and lives on other snakes, very likely the Calamariæ. (5) Callothis nigrescens, which grows to about 4 feet in length, is black in the upper parts and red in the lower.

(6) The first class of the Viperine snakes is the Dabria clegans called by Europeans in India the Chain Viper and in Ceylon the Tic Polonga The fangs are very long, and for this reasun, together with its fierceness, it is the most dreaded snake in India. Its poison acts differently from that of the cobra. Its tenacity of life is really wonderful, it having been known to live for a whole year without food. The length of this snake rarely exceeds 5 feet. (7) The Echis carinata and the last-named class are the only true vipers in India. The harmless "brown tree snake" (Dipsas gokool) is frequently confused with the Echis carinata, but they are easily distinguished by the scales on the head of the latter, while the Dipsas gokool has plates or shields. (8) The green tree viper (Trimeresurus anamallcnsis) is one of the family of Crotalidæe or pit vipers, so named from the pit or cavity beneath the eye and the nostril, of which family the terrible rattlesnake of America is a member. In Inclia there are eight species of Trimeresuri, but up to the present only one has been found in Bombay, though it has been stated that another species, T. strigatus has been seen far up the country. (9) The headquarters of the Hypnale nera, or Carawala, are in Ceylon, but it is commonly found along the Malabar coast.

These classes include all the poisonous land-srakes. All the true sea-snakes are poisonous, and of these, amongst others, the following are in the Bombay collection: Hydrophis niadema, Hydrophis robusta, Hydrophis curta, Hydrophis an ifasciatus, Hydrophis Phitsoni, Hydrophis Guntheri, Hydronlits Lindsayi, Hydrophis chloris, Enrthydrina bengalensis, Pelamis bicolor.

\section{SCIENTIFIC SERIALS.}

Rendiconti del Reale Instituto Lombardo, May. - Foraminifera of Mount S. Colombano Lodigiano, by Dr. tirnesto Mariani. A classified list is given of these organisms, collected chiefly by Profs. Maggi and Balsamo Cuvelli in the district stretching from the right bank of the Lambro to within a few miles of the P'o. The prevalence of Miliolide and allied forms shows that this fauna, which mostly still survives in the surrounding seas, flourished in the warm shallow waters which at a remote epoch flooded the plains of Lombardy. - On the use of the lucimeter in agriculture, by Prof. Giovanni Cantoni. The author's recent experiments with this instrument, first designed by Bellani, show that it is calculated to render great service to husbandry in combination with the thermometer and psycrometer.-Alberto Brambilla continues his paper on a certain class of algebraic surfaces; and Prof. A. Scarenzio has some remarks on the therapeutic properties of the arsenical thermal waters of Acquarossa, near Biasca, on the old St. Gothard road in the Canton of Ticino.

June 7.- On the normal curves of genus $p$ of various spaces, by Prof. E. Bertini. Clifford's fundamental theorem is here established by a more synthetic method than any hitherto publi:hed demonstrations. The theorem itself (Philosophic Transactions, 1878, p. $68 \mathrm{I}$ ) is here announced in the following modified form :-A curve of genus $p$ and order $n>2 p-2$ cannot belong to a space of more than $n-p$ dimensions. - On the proposed sanitary legislation for Italv, by D. C. Zucchi. A calculation is made that by the adoption of such measures as are enforced by the Local Government Boards in Great Britain, the average mortality of the population might be reduced from over 27 to under 20 per thousand. This is shown to be equivalent to the rescue of 100,000 lives, whose labour for 300 working days represents an annual sum of nearly $£ 5$, oco, ooo at present lost to the nation.- Meteorological observations made at the Royal Observatory of Brera, Milan, for the month of May.

\section{SOCIETIES AND ACADEMIES. LONDON.}

Royal Society, June I4.- "The Minimum-point of Change of Potential of a Voitaic Couple." By Dr. G. Gore, F.R.S.

In this communication is described the following very simple method of detecting the influence of the minimum proportion of 